\title{
MEDIA IMAGE MANAGEMENT AND PROVOCATION - A CASE STUDY OF WOJCIECH CEJROWSKI
}

\section{Abstract}

The article is an attempt to characterize provocation as an instrument for creating a media image. The author, using the method of qualitative research, illustrates the ways of using provocation during image activities on the example of Wojciech Cejrowski. On the basis of the research, he finds out which factors determine the form of image creation in the media. Moreover, the author defined reasons and effects for using provocations in the process of building media image.

Keywords: provocation, media image, personal brand, media management, Wojciech Cejrowski

JEL: M3, Y8, Y9

\section{Introduction}

Nowadays, the presence in the media is one of the most frequently chosen marketing methods to guarantee the growth of popularity of an individual or organization. The global reach of such media as television, radio, or press is a very important factor in the process of media image building. Owing to the omnipresence of mass media, the subject of marketing activities has a chance to reach a huge group of recipients all over the world. Taking into account the multitude of current messages, it is increasingly difficult to attract the viewer, listener, or reader. Searching for new methods, aimed at generating popularity growth, has made provocation an increasingly popular instrument of marketing activities. Currently, controversial content appears in the mass media much more often than a few years ago. Many scientists believe that the provocation used in them is identical to manipulation. Provocation is a particular form of manipulation. The popular stereotype of manipulation equates it with either covert, even conspiratorial, influence (Karwat, 2007). Every 
act of provocation is manipulation because it seeks to artificially evoke, arouse, strengthen, inhibit, suppress, extort, and arbitrarily direct other people's experiences, impressions, images, aspirations, decisions, and actions (d'Almedia, 2011).

Managing the activity of media audiences is currently one of the biggest challenges for media entities (Kraft, 2015). One of the instruments to stimulate the engagement of viewers, listeners, readers or internet users is provocation - one type of manipulation and persuasion in advertising and personal brand management. The word 'provocation' means a deceitful action aimed at persuading someone to act in a certain way, usually fatal in consequences for that person and people connected with him/her (Percy, Rossiter, 1992). Such a description emphasizes the negative character of provocation, manifesting itself in an attempt to harm another person. It takes the form of a vulgar, unbecoming, deliberate hoax, and trickery (Sternthal, Craig, 1973). This statement can be identified with the phenomenon of personal brand management, which persuades recipients to make certain choices or behaviors. Moreover, it generates their feelings and emotions in a certain way. It is, however, impossible to resolve the issue of whether this is disadvantageous to them in each case.

Nowadays, a brand is associated with various aspects of social and economic life. Thus, not only products and services have their brands, but also geographical regions, cities, organizations and individuals. In relation to the last of these entities there is talk about personal brand and its building (personal branding). From the point of view of management, a brand is a set of benefits that become its user, which benefits are provided by the product marked with a given name or symbol (Urbanek, 2008). A person with a strong personal brand is therefore a person recognizable in a specific environment, who in addition, due to contacts with him/ her, evokes positive associations (Białopiotrowicz, 2009). People interested in conscious personal branding not only participate in social media, but also create websites, run blogs or microblogs, publish articles in the form of podcasts and videocasts, use Wiki-type tools (Vitberg, 2009).

The research problem of this paper is the phenomenon of provocation as an element of image building of Wojciech Cejrowski. The main objective of the article is to determine the strategy of image management based on provocation in the Cejrowski's case. The basis of the source base is the analysis of the activity of Wojciech Cejrowski, who over the years has repeatedly used this instrument for marketing purposes. This paper is aimed at establishing answers to the following research questions:

(1) What are the characteristics of Wojciech Cejrowski's media image building strategy?

(2) What are the reasons and effects for using provocations in the process of building media image in case of Wojciech Cejrowski?

On the basis of the assumptions of this paper, several other aims can be detailed in it. One of them is to show the actions of Wojciech Cejrowski, who are 
determinants in the process of media image creation. Moreover, this paper contains other problems in the field of social science research. The content of the research work gives an opportunity to compare how the media activity of Wojciech Cejrowski has changed over the years.

Previous publications dealing with the issue of provocation in the process of media or image management have discussed the topic primarily from the perspective of advertising. In the English-language academic literature there is a lack of studies that are case studies dedicated to discussing provocation in the process of image management in terms of personal branding. The vast majority of articles and research in this field address the issue of shockadvertising or provocation as a phenomenon in its entirety. Due to the fact that many studies on personal branding are advisory, the considerations are supported by brand management theory and supplemented with authors own reflections. The point of departure for the undertaken research is the analysis of Wojciech Cejrowski's behaviour, clothing, lifestyle and statements, which are the factors determining his media image.

The author based his research on the strategy of qualitative research. He considered this approach to be the most appropriate to find answers to the research questions. A huge amount of hypothetical source material (more than 30 years of Cejrowski's activity) also influenced the choice of the qualitative type of research. The research type of this article is a case study. Robert K. Yin ${ }^{1}$ recommends using the case study method to find answers to exploratory questions about 'how' and 'why' a phenomenon occurs (Yin, 2009).

The main research method is the method of content analysis. As source material for the research, the author used the content available on the official website of the subject under study. In addition, the research sample included Internet articles describing the provocative behavior of Wojciech Cejrowski. For this purpose, the author used the Google search engine, in which he entered the following keywords: Wojciech Cejrowski, affair, scandal, provocation, shocking, sensation, incident, row. Due to the vastness of the source material, the author made a purposeful selection and chose those contents that, in his opinion, best characterize the described phenomenon. In the article author approaches particular aspects of the presented phenomena and relations as 'telling', that is, "serving to make previously obscure theoretical relationships suddenly apparent" (Mitchell, 1984). Thus, the analyzed facts and relations ('cases') are chosen, for the "best provide insight into the social phenomenon to be investigated" (Emmel, 2013).

Moreover, the author of the research work has analyzed all published books (nine in total) of this controversial author. Other activities that form the basis of the research also include a review of the domain publications of Wojciech Cejrowski's life. Due to the privacy of the traveler, only two books describing his life appeared

1 Robert K. Yin is an American social scientist, known for his work on case study research as well as on qualitative research. Over the years, his work on case study research has been frequently cited. 
on the market (Brzozowicz, 2010; Królikowska, Rott, 2010). The research sample also included a publication by the American political scientist David Ost (1999), which is an analysis of extreme right-wing movements in Central and Eastern Europe. His research cited Cejrowski's provocative behavior in the media as an example of a representative of Polish right-wing.

\section{Personal brand management in terms of media image}

A personal brand is a concept that is rooted in social interactions. It relates to the realization of an individual's goals in the social area, but also to the theory of personal brand management (Walczak-Skałecka, 2018). Referring to the understanding of brand proposed by Leslie de Chernatony, a personal brand can be considered as an identifiable person who represents lasting values recognized by the recipient as those which to the highest degree satisfying their needs (de Chernatony, 2003). Consideration of personal branding shifts toward a particular category of thinking about the individual. Tom Peters (1997) has taken as a starting point the state in which every individual has a personal brand. Of course, not everyone consciously, consistently, and effectively manages it. The definition of a personal brand could be as follows - a personal brand is creating by a person who consciously takes actions to identify, create and communicate values that can be considered by a certain group of recipients as satisfying their needs to the fullest extent (Rampersad, 2008).

Personal brand management is related to a management approach from a marketing perspective (Nierenberg, 2011). In marketing terms, management

(...) is the process of planning and executing ideas for the pricing, promotion, and distribution of goods, services, and ideas designed to bring about an exchange that meets the expectations of targeted customer groups and organizations (Kotler, 1988, pp. 12-13).

Referring to the understanding of brand by management science, personal brand can be defined as the sum of benefits (values) that it brings to all the entities who have contact with a given brand (Wojtaszczyk, Maszewski, 2014). The attributes of a strong personal brand are its high level of awareness and positive image, which are the foundation of trust in the brand (Dowling, 2001).

The media image, according to the American Marketing Association, is the result of the consumer's perception of a product, institution, brand, business, person, which does not have to be consistent with reality and facts. Thus, it is the result of the recipient's perceptions, which do not have to be related to truth and reality. A media image is also the structure of images that determine the perception of an individual, an institution, or another group in the minds of media messages recipients (Smeesters, Mandel, 2006).

Nowadays, an image can be created in two ways: through image self-creation (directly by the person/organization concerned) and through the media (media image, 
often independent of the activities of the subject concerned). Building an image that increases the number of supporters or observers and is aimed at consciously multiplying profits enables conscious self-creation. Its use is facilitated by the social media environment, which gives the author the possibility to control the content of the published messages. Unlike traditional media, which create a media image, some new media (e.g. Facebook or Twitter) promote conscious self-creation. The content available on television, radio, newspapers (including the Internet) is repeatedly posted without consulting the subject, which can have a negative impact on the images built in the minds of the recipients.

Over time, the importance of the media image began to grow, and the $21^{\text {st }}$ century is a period in which many entities cultivate their image extremely strongly. Many individuals, institutions, companies and other groups are striving to make their image reliable, clear, and concrete, and to build a positive reputation for the object it concerns. According to Eleri Sampson's external image should be the same as the skills, qualifications, aptitudes, and values that an individual presents to society (Sampson, 2002).

\section{Provocation in the process of building brand image}

The word provocation comes from the Latin word 'provocatio' and means calling, challenge, appeal. The etymology of this term refers to another word used in Latin - 'provocator', that is, 'calling (to battle)'. A provocation (in semantic meaning) is an action aimed at obtaining specific information or at forcing the recipient's behavior through the deceitful and deliberate action of a third party (Eco, 1976). In legal terms, provocation means inducing a person to commit a crime in order to bring about criminal proceedings against them. ${ }^{2}$ Another meaning of the word is an action aimed at shocking someone, evoking certain emotions or uncontrolled behavior in someone (Gelb, Hong, Zinkhan, 1985).

In the history of mankind, there have been many instances of unintended use of words in the media. This was often due to the lack of a planned advertising campaign or ignorance of consumer behavior research. Another reason was simply the wrong choice of words. Such action involves the risk of losing the trust, prestige, and value promoted by a brand, an individual, an institution, or another group that is the subject of marketing activities. It may happen that as a result of controversial advertising, which negatively affects the image of a given object, the public opinion will begin to associate it primarily with an unintended action. It is connected with a complete remodeling of the image developed so far and may lead to the loss of the number of fans, spectators, readers, and, as far as goods are concerned, to a decrease in interest in its purchase. It should be remembered that this also works the

\footnotetext{
2 In the case of Polish legal regulations.
} 
other way round - it is also possible that an unknowingly applied provocation in an advertisement will make its reception positive.

An example of unknowing provocation in a media message can be an unfortunate advertisement for a Mountain Dew drink. The producer of this product wanted to present an unconventional advertisement, but it turned out that the main slogan unwittingly persuades customers to masturbate. The British branch of the brand boasted an animated picture (by Twitter) on which a thirsty man drinks a bottle of refreshing drink. Although the picture itself is harmless, it turned out to be a bit more difficult to choose the words used in the campaign. The customers from Scotland laughed at the slogan "Epic thrills start with a chug". They had a good reason to do so. 'Chug' is a popular term in Scottish slang for masturbation. In addition, the whole graphic was given an equally funny description, "We didn't choose the chug life, the chug life chose us", which caused even more controversy.

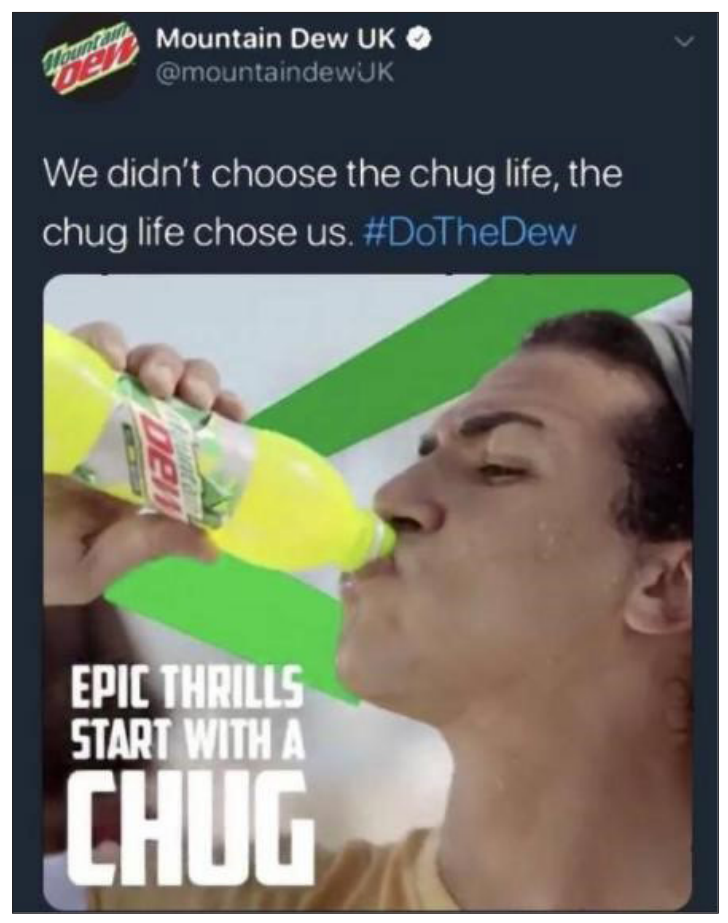

Figure 1. Advertising provocation of the Mountain Dew

Source: https://9gag.com/gag/argQyGy

(publication date: 28.08.2018; accessed: 3.12.2020) 
Advertising provocations are thoroughly thought-out and planned actions, resulting from, among other things, consumer behavior research. Advertisers are in this case the subject, while the recipients are the object of influence, which becomes a tool to facilitate the achievement of specific objectives (De Pelsmacker, Van Den Bergh, 1996). Advertising message, which contains elements of provocation, is based primarily on the emotions of the person to whom it is addressed. According to Daniel Goleman, emotions can be called any movement or disturbance of the mind, feelings, passions, and any state of mental agitation or excitement (Goleman, 1995). Referring to the emotional sphere is one of the elementary methods of conveying advertising content.

The basic feature of the controversial message in advertising is a transgression ${ }^{3}$ (Mortensen, 2013). In terms of the issue considered in this article, this issue means exceeding social norms and taboo. A transgressive advertising message is much more likely to be remembered by a potential recipient. This results in maximizing the use of provocative and shocking advertising (Mortensen, 2013).

The growing number of controversial advertisements and the practice of increasingly questionable means of expression can be considered a cultural phenomenon. This kind of advertising messages often exceeds contemporary cultural norms and patterns, while at the same time broadening the framework of what is considered acceptable, due to its universality. The dynamic at which social acceptance of all sorts of impulses and different behaviors increases is fast, which affects the dynamic at which limits are crossed. In the past, the woman's knee was seen as a highly inappropriate act. Nowadays, the sight of distracted female representatives in TV broadcasts is not considered to be something extraordinary.

\section{Case study of Wojciech Cejrowski}

Wojciech Cejrowski ${ }^{4}$ is a traveler, indigenous or endangered tribes, a TV personality, a popular radio journalist, a cabaret artist (he says: I am a comedian), a writer and publicist, a satirist - a fervent critic of bureaucracy and socialism, a music critic, a photographer, and a carpenter by profession. Cejrowski undoubtedly has an unconventional personality. He is sharp, expressive, and uncompromising - for some, it is an advantage, for others his biggest disadvantage. There is a belief that he is generous in criticism and sparing in praise. Cejrowski's traveling activity,

3 A social transgression, violating a norm.

4 Probably he was born in $27^{\text {th }}$ of June 1964 in the neighborhood of Elblag (Poland). This is an unconfirmed information - Cejrowski himself denies that he would be born in the vicinity of this town. On the website of info.elblag.pl, he denied being born over there, saying the following: "I am a Kociewiek, that is, I grew up in Kociewie and that is where I come from, my whole family comes from, our roots are there. Apart from this information, I never give anything else, because you have privacy once." 
popularized by TV programs and books, although it brought him great success among viewers and readers, became the object of criticism from Latin-American Researcher Marcin Florian Gawrycki in his book. Gawrycki counted Cejrowski as a 'travelbrite, 5 in other words - traveling celebrities proclaiming a simplified image of exotic peoples of the world.

Wojciech Cejrowski is a persona who often arouses controversy with his statements or behavior. Since the beginning of his media career, he has not concealed his views. He was often a hero or anti-hero of newspaper titles that reported on his controversial statement or behavior. Such a sequence of things makes Wojciech Cejrowski's views influence the creation of his media image. Analyzing the way the traveler expresses them, one can certainly find elements of provocation, causing his interest in a large crowd of recipients. Some political scientists unequivocally classify Cejrowski as a persona with views consistent with those of the extreme right. One of them is David Ost, an American scientist dealing with the subject of Polish political transformation. In his article, devoted to the extreme right-wing in Poland, he mentions Cejrowski among people with such a worldview (Ost, 1999). Another scientist, who shares Ost's opinion, is Dariusz Galasiński, who wrote in his book that Cejrowski often publicly stresses his aversion to certain ethnic groups, such as Roma, Gypsies, or Jews (Galasiński, 2000). Moreover, both claim that in the program Barefoot Around the World 6 there are racist statements, directed against the different racial origin.

Over the years Wojciech Cejrowski has shocked public opinion on many occasions. One of the most controversial issues is burning the European Union flag when he was a guest of a television program at the Polish public television (TVP). In 2017, during a journalistic program in which he performed together with Michał Rachoń, both gentlemen raised issues related to the European Union. Suddenly Cejrowski took out the flag of this organization and decided to burn it. The program was not interrupted, and when the paper flag with twelve stars on the blue background was destroyed, Cejrowski said: "In America, if you did something like that, nobody would even be interested in it. This is a piece of paper, this is my property and I can do with it whatever I like in my cabin". In addition to the anti-European Union manifesto, Cejrowski challenged the legal provision concerning the desecration of national symbols. Later he added: "The European Union is not a state and therefore its emblem is not protected by any regulations other than patents. Someone has bought himself a flag, he can burn it if he wants."

Between appearances on television or radio, Cejrowski occasionally deals with preparing reviews. In 2018 he decided to review Wojciech Smarzowski's film Cler$g y^{7}$ in a few sentences, even though he admitted publicly that he did not watch it at

5 A combination of two words: traveler and celebrity.

6 Polish title: Boso przez świat.

7 Polish title: Kler - a Polish movie criticizing the Catholic Church. 
all. On Radio Zet, when asked about his feelings connected with this production, Smarzowski said in very controversial words:

I don't have to watch the film to trust other people's opinions, just like I don't have to watch my own stool guts, but I can trust the doctor who put the probe in there, he put the sight glass in my back. I don't have to watch the movie from my own ass. With regard to the film Clergy I have exactly the same.

If Cejrowski's goal was to arouse controversy among the audience, he can certainly consider his provocation as successful, because the statement resulted in many calls to the editorial office where he spoke the words. Taking into account the fact that several Internet news services wrote about this situation, the more Cejrowski's media image has been recorded in the minds of media recipients.

Wojciech Cejrowski, despite many declarations that put him in the light of a believing Catholic, was able to speak negatively even about the head of the Catholic Church. His commentary on the pontificate of the current Pope Francis I reservations considerable doubts among the public opinion. In 2013, during a conversation with one of the Internet portals, he decided to evaluate the Argentinean Pope in strong words. He expressed his disapproval in the following way:

When I see him in sloppy shoes, in liturgical robes when he performs the liturgy, he is the governor of Jesus Christ on Earth, King of Kings, I would expect him not to have those awful shoes. I know that St. Francis of Assisi was also shocked by his behavior, he chased the naked man.

At the end of the conversation he decided to verbally attack the Pope directly. He commented not only on his pontificate in the theological aspect, but also on the profane sphere of the most important person in the Catholic Church. Cejrowski appealed:

I am weaker from theology than Terlikowski ${ }^{8}$ and I read it to myself, and he says that Francis is very weak in theology. Not every pope has to be strong in theology, but he is simply weak. Benedict was excellent in theology, while Francis is poor, his speech is weak, the sermons he preaches are quite empty from my point of view, shallow. These are such Latino circles. He didn't say anything like that and didn't finish it... He's spinning and spinning. Say something concrete to the man!

Not even a year has passed since the controversial statement on Francis I, and Cejrowski once again decided to provoke the media experts (and not only) with his statement. This time his opinion was not connected with clergy or the institution of the Church. The traveler decided to comment on the event which took place on November $11^{\text {th }}$ during the Independence March in Warsaw. In 2013, during the Independence Day celebrations, unknown perpetrators set fire to a rainbow, which is a symbol of the LGBT environment, located in Warsaw's Savior Square. In addition,

8 Tomasz Terlikowski - Polish journalist related to publications about the Church. 
also unknown individuals set fire to a shelter on the premises of the Russian Embassy, also located in Warsaw. The day after the rainbow was burned on Savior's Square Cejrowski decided to express himself on this subject, through his Facebook. Post account, sounded as follows: "The Rainbow on Savior's Square was burnt. Finally! This is Savior's Square, not the Square of Perverts".

Cejrowski did not stop at commenting on the burnt rainbow. A few hours later he posted an equally controversial entry. Another issue he decided to subject to provocative criticism was the fact of setting fire to a shelter located on the premises of the Russian Embassy in Warsaw. In his entry, Cejrowski blames the police for this act of vandalism: "Every Pole has the constitutional right to throw everything he wants at the Russian embassy (not the people, only the property) and the police have the duty to effectively defend the diplomatic post even of such a hostile state as Russia." Cejrowski's scandalous entries were publicly commented on by Michał Wiśniewski, a person known primarily in the Polish show business community. The musician in his statement evaluated not only what Cejrowski said, but also the very lifestyle of the traveler. A former participant in the Eurovision contest said on public television:

He can do the most wonderful nature shows in the world, but he is an absolutely crazy man who has no right to remind us that in the name of the Constitution, we have the right to throw down the Russian embassy and burn Polish police booths.

It is worth noting that Wiśniewski very rarely decides to make a public comment on political or social issues. It is possible that as a result of Cejrowski's controversial opinions, he was provoked to speak on this matter.

\section{Gestures, clothing and body language - factors for building the audience's attraction}

Human communication is not just words. Gestures and (broadly understood) body language are also very important in this process. Moreover, clothing and its additional elements play a significant role in communication. The role of the body, which consists, among other things, of external appearance, causes that the spoken words can be interpreted in completely different ways by their addressee.

According to the American anthropologist Albert Mehrabian (1987), non-verbal communication is much more important than that based on the use of words. He confirmed his hypothesis with research results. Mehrabian research proved that as much as $55 \%$ of non-verbal communication is non-verbal. In the next position, he classified the sound of the voice, to which he attributes $38 \%$, and at the very end, there are words $-7 \%$ (Mehrebian, 1987). 
Analyzing the way how Cejrowski communicates in front of the camera, one can certainly state that non-verbal communication is of colossal importance during his speeches. Apart from sophisticated vocabulary, colorful comparisons, and controversial comments, Cejrowski is known by great expression during his gestures. In one of the episodes on public television, he himself stated on air that he has "overexpression of movement". This was due to the context when Cejrowski was explaining to the host of the program why he does not want a glass of water to stand near him. Other examples of Cejrowski's gestures are episodes of his program Barefoot Around the World. In one of them, Cejrowski operated his hands so hard that at some point he hit the lens. The editor decided to publish this fragment.

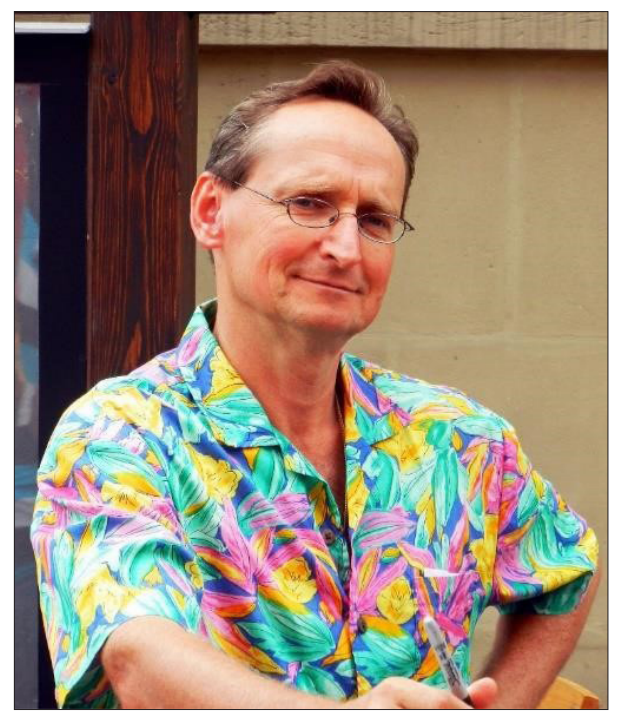

Figure 2. Wojciech Cejrowski in his characteristic shirt

Source: https://commons.wikimedia.org/wiki/File:Wojciech_Cejrowski_2011.jpg (publication date: 12.08.2011; accessed: 3.12.2020)

An important element of non-verbal communication, which characterizes Cejrowski, is also clothing. For many years now, an opinionated traveler has been associated with the public opinion with wearing multi-colored shirts. Cejrowski in each episode of Barefoot Around the World is dressed in a shirt, which very often has a bold color. Such a turn of events is hardly surprising because the episodes of this cycle are very often shot in exotic parts of the world, with which such clothes are associated. However, it is unusual that Cejrowski often appears in this type of clothing in journalistic programs or even during scientific conferences. The characteristic shirt, over the years, has become for him something more than just an element of his media image. Since 2005 he started selling this type of clothing in the Colonial Store, which he owns. Such a sequence of things made people who are admirers 
of Cejrowski or often agree with his views, got the opportunity to identify with him by wearing shirts in extravagant designs. Analyzing all the years of Cejrowski's media activity, it is highly probable that this type of outfit brings him certain benefits, because for many years he has not changed the style of his clothes.

\section{Conclusions}

Provocation is an instrument that is used when building a media image. It is proved by the analysis of specific content, on the basis of which its application was described in detail. Cejrowski is an example confirming the thesis contained in the title of the work. The figure of him made it possible to show the research problem in a different way and to describe the analyzed phenomenon in terms of content.

It seems impossible to state unambiguously whether provocation is an effective tool in the process of media image creation. In the case analyzed in this paper, one can see both positive and negative effects, which are derivatives of such activities. By some publicists, Cejrowski is considered to be one of the so-called 'travelbrities'. Considering what this term means, any mention of Cejrowski in the media seems to be beneficial for him. This has to do with the unwritten rule in the world of mass media, according to which "no matter how - as long as it is loud about me." Thanks to his presence in various types of relays, directed to a specific group of recipients, Cejrowski had a chance to reach a very wide audience. Regardless of his liking or lack of liking, the recipients of the media had regular contact with him, which had an impact on building his media image.

Due to the extremely different perception of his person, Cejrowski decided to create two Twitter accounts. One is called 'Wojciech Cejrowski' and the other one is 'Wojciech Cejrowski for the bold'. The first profile is only related to travel activities. There are no political opinions or comments containing Cejrowski's worldview. The second account, on the other hand, is a place where the traveler posts only entries concerning current events on the political scene. This dualism, which Cejrowski uses on Twitter, is caused by a wave of unfavorable comments, which previously appeared under his entries in another social medium - Facebook. This case answers well the question of research of which factors determine the form and style of media image creating. In Cejrowski's example, one of the most important factors is a feedback of his recipients.

Controversial statements, behaviors, and manifestos by Cejrowski have brought him many benefits. Not only in terms of image but also financial. Thanks to exposing the Yerba Mate drink and dressing up in shirts, Cejrowski made selling these things an additional source of income. Moreover, he created something that, according to media image experts, is extremely important in creating his own image

9 A person known for his or her travels. 
- a symbol. The colorful shirt and drinking vessel Yerba Mate is very often associated with the figure of Cejrowski, not only by his audience, listeners, or readers. Scandalous statements and questionable behavior of the traveler have influenced the high publicity of this person. This is evidenced by the fact that many websites contain the words 'Wojciech Cejrowski' in their content. Using the Google web browser, more than 1.750 .000 pages pop up after typing in the traveler's name and surname, which wrote about him. ${ }^{10}$

The use of provocation in the process of media image building also has some consequences. Due to his controversial statements, Wojciech Cejrowski has had a number of court cases in his portfolio. One of them ended unsuccessfully for him. The traveler had to pay three thousand PLN in fines for insulting the former President of Poland - Aleksander Kwaśniewski. Considering the legal aspect, this was the most painful consequence he suffered during his media career. Moreover, Cejrowski was repeatedly expelled from the media in which he worked, including the most popular titles of newspapers, radio stations, and television channels in Poland. On the one hand, this fact can be seen as an insult because it gives him the testimony of an unstable person. Moreover, it is difficult to give such a person the credit of trust. Looking at it from a different perspective, however, it must be said that thanks to this situation, Cejrowski had a chance to appear in front of a very wide audience. For more than two decades of his career, he was an employee of several television and radio stations and press titles. Such a turn of events enabled him to reach different audience groups, not necessarily of the same profile.

There is a high probability that if it wasn't for such frequent employer changes, he wouldn't be as popular today as he is. So, if you look at it in terms of media coverage, in a sense Cejrowski may consider his failures as a success. It is worth noting that he has been using provocation for over 30 years and still does not change his image-building strategy. Taking into account the fact that during those years he has been constantly moving in public space, one can say that in his case provocation is a very effective tool of image building. If it had been the other way round, Cejrowski would probably have abandoned this communication strategy and would not have generated such a large audience on television ${ }^{11}$ or had a large number of books sold. ${ }^{12}$

10 Data as of $1^{\text {st }}$ of December 2020.

11 New episodes of the programme Boso przez świat are watched by an average of 900.000 viewers each. According to Wirtualne Media.pl, over 1.1 million viewers tuned in on 28 of Ferbuary 2021 to watch the first episode.

12 According to Natemat.pl in 2010, his book Gringo wśród dzikich plemion earned PLN 1.87 million on sales. 


\section{Bibliography}

Almeida F. d' (2011). La manipulation. Paris: Presses Universitaires de France.

Białopiotrowicz G. (2009). Kreowanie wizerunku w biznesie i polityce. Warszawa: Poltext.

Brzozowicz G. (2010). Cejrowski. Biografia. Poznań-Warszawa: Zysk i S-ka; Wydawnictwo Czerwone i Czarne.

Chernatony L. de (2010). From Brand Vision to Brand Evaluation. London: Routledge.

De Pelsmacker P., Van Den Bergh J. (1996). “The Communication Effects of Provocation in Print Advertising". International Journal of Advertising, 15(3), pp. 203-222. DOI: https:// doi.org/10.1080/02650487.1996.11104652.

Dowling G. (2001). Creating Corporate Reputations. Oxford: Oxford University Press.

Eco U. (1976). A Theory of Semiotics. Bloomington: Indiana University Press.

Emmel N. (2013). Sampling and Choosing Cases in Qualitative Research. London: Sage.

Galasiński D. (2000). The Language of Deception: A Discourse Analytical Study. London: Sage.

Gelb B., Hong J.-W., Zinkhan G. (1985). "Communications Effects of Specific Advertising Elements: An Update." Current Issues and Research in Advertising, 8(1), pp. 75-98. DOI: https://doi.org/10.1080/01633392.1985.10505384 (accessed: 3.12.2020).

Goleman D. (1995). Emotional Intelligence. New York: Bantam Books.

Karwat M. (2007). Teoria prowokacji. Warszawa: Wydawnictwo Naukowe PWN.

Kotler Ph. (1988). Marketing Management: Analysis, Planning, Implementation, and Control. Cambridge: Longman Higher Education.

Kreft J. (2015). Za fasada społeczności. Elementy zarządzania nowymi mediami. Kraków: Wydawnictwo Uniwersytetu Jagiellońskiego.

Królikowska B., Rott D. (2010). Strategie autoprezentacyjne w reportażach podróżniczych Wojciecha Cejrowskiego. Sosnowiec: Oficyna Wydawnicza "Humanitas".

Mehrebian A. (1987). Eating Characteristics and Temperament: General Measures and Interrelationships. New York: Springer-Verlag.

Mitchell J.C. (1984). “Typicality and the Case Study”. In: R. Ellen (ed.). Ethnographic Research: A Guide to General Conduct. London: Academic Press.

Mortensen. K. (2013). Maximum Influence: The 12 Universal Laws of Power Persuasion. New York: Amacom.

Nierenberg B. (2011). Zarządzanie mediami. Ujęcie systemowe. Kraków: Wydawnictwo Uniwersytetu Jagiellońskiego.

Ost D. (1999). “The Radical Right in Poland: Rationality of the Irrational”. In: S.P. Ramet (ed.). Radical Right in Central and Eastern Europe Since 1989. University Park, PA: Penn State University Press, pp. 85-107.

Percy L., Rossiter J. (1992). “Advertising Stimulus Effects: A Review.” Journal of Current Issues \& Research in Advertising, 14(1), pp. 75-90. DOI: https://doi.org/10.1080/10641734.1992. 10504982 (accessed: 1.12.2020).

Peters T. (1997). “The Brand Called You”. Fast Company, 10.

Rampersad H. (2008). Authentic Personal Branding: A New Blueprint for Building and Aligning a Powerful Leadership Brand. Charlotte: Information Age Publishing.

Sampson E. (2002). Build Your Personal Brand. London: Kogan Page.

Smeesters D., Mandel N. (2006). "Positive and Negative Media Image Effects on the Self." Journal of Consumer Research, 32(4), pp. 576-582. DOI: https://doi.org/10.1086/500489 (accessed: 1.12.2020).

Sternthal B., Craig S. (1973). "Humor in Advertising." Journal of Marketing, 37(4), pp. 12-18. DOI: https://doi.org/10.1177/002224297303700403 (accessed: 3.12.2020). 
Vitberg A.K. (2009). "Analog vs. Digital Personal Branding - A New Twist on Personal Marketing Plans." CPA Practice Management Forum, 10, pp. 10-19.

Walczak-Skałecka A. (2018). "Granice pojęcia «marka osobista»." Annales Universitatis Mariae Curie-Sklodowska, sectio I: Philosophia-Sociologia, 43(1), pp. 270-286. DOI: http://dx.doi. org/10.17951/i.2018.43.1.269-286 (accessed: 3.12.2020).

Wojtaszczyk K., Maszewski F. (2014). "Różnorodność metod zarządzania marką osobistą." Prace Naukowe Uniwersytetu Ekonomicznego we Wrocławiu, 349, pp. 454-462. DOI: https:// doi.org/10.15611/pn.2014.349.38 (accessed: 5.12.2020).

Yin R.K. (2009). Case Study Research: Design and Methods. Thousand Oaks-London: Sage.

\section{Internet sources}

Cejrowski W. (2017). “Moje wartości”, https://cejrowski.com/moje-wartosci/ (accessed: 1.12.2020).

Dziennik.pl (2013). “Cejrowski: Każdy Polak ma konstytucyjne prawo obrzucać ruską ambasadę”, https://wiadomosci.dziennik.pl/opinie/artykuly/442953,cejrowski-kazdy-polak-ma-konstytucyjne-prawo-obrzucac-ruska-ambasade.html (accessed: 1.12.2020).

Dziennik.pl (2013). “Wiśniewski: Cejrowski jest absolutnie szalonym człowiekiem”, https:// rozrywka.dziennik.pl/plotki/artykuly/443581,michal-wisniewski-uwaza-wojciecha-cejrowskiego-za-szalonego-czlowieka.html, 21.04.2019 (accessed: 1.12.2020).

Dziennik.pl (2013). "Cejrowski bije w papieża: Kazania głosi dosyć puste”, https://wiadomosci.dziennik.pl/opinie/artykuly/445726, wojciech-cejrowski-krytykuje-papieza-franciszka.html (accessed: 1.12.2020).

Mazur J. (2018). “Wojciech Cejrowski - życiorys”, https://zyciorysy.info/wojciech-cejrowski/ (accessed: 1.12.2020).

Mindykowski M. (2012). "Bóg słucha i się cieszy. Rozmowa z Wojciechem Cejrowskim”, https:/dziennikbaltycki.pl/bog-slucha-i-sie-cieszy-rozmowa-z-wojciechem-cejrowskim/ ar/643277 (accessed: 1.12.2020).

Pałys K.f. (2012). “Reklama agresywna musi wzbudzać jak najwięcej kontrowersji”, https://manager.money.pl/strategie/marketing_i_sprzedaz/artykul/reklama;agresywna;musi;wzbud zac;jak;najwiecej;kontrowersji,129,0,1210753.html (accessed: 1.12.2020). 
